spite of such treatment. In this outbreak, thirty-two people received either succinylsulphathiazole, chloramphenicol or tetracyclines. Nine patients received no specific treatment and there is no evidence of any difference in the duration of symptoms in the two groups.

The organism eventually proved resistant to succinylsulphathiazole and sensitive to streptomycin, chloramphenicol and the tetracyclines, but by the time this information was available the majority of cases had recovered. It would be unwise to disregard the potential value of chemotherapy, however, particularly in view of the possibility of invasion of the blood stream with spread beyond the alimentary tract and there is some evidence that chloramphenicol is of value in this type of case (Hines, I95 I). It would therefore be wise to use either chloramphenicol or the tetracyclines as a routine measure in all these cases.

\title{
REFERENCES
}

Hines, A. (195 r). F. Amer, med. Ass, 147, 248.

Kronenberger, F. L. \& Smith, H. C. (1956). Brit. F. Tuberc. 50, 225.

Levine, M. G. \& Plattner, E. B. (I944). Amer. F. clin. Path. 14, 342.

Public Health Laboratory Service (1955). Mon. Bull. Minist. Hlth Lab. Serv. 14, 203.

Rubenstein, A. D. \& Johnson, B. B. (1945). Amer. F. med. Sci. 210, 5 I7.

Seligmann, E., Saphra, I. \& Wassermann, M. (1946). F. Immunol. 54, 69.

\section{Protecting food at home and in the canteen}

\author{
By Lucy C. Currie, Glasgow and West of Scotland College of Domestic Science, \\ I Park Drive, Glasgow, C.3
}

To prepare housewives and canteen workers for what is, truly, an unremitting battle, we must continue to pinpoint for them: ( $I$ ) the foods most vulnerable to bacterial contamination such as manipulated meats and reheated dishes; (2) the channels through which any food may be attacked; (3) simple practical ways of preventing contamination. Infestation by non-bacterial agents, e.g. weevils, is of less importance, because contamination is more obvious. Care must be taken to destroy the pests before the food is discarded, to prevent further spread of infestation.

Good work towards education in food hygiene has been, and is being, done by well-tried propaganda methods: this must be continued, and interpreted in a practical way, in homes by health visitors, and in canteens by manageresses.

Before staff in canteens is willing to learn and undertake the necessary discipline of food handling, conditions must encourage good teamwork. The following practical aids, some of which are embodied in the new Food and Drugs Act, should be considered (I) proper delegation of duties and responsibilities; (2) attractive, sufficient, effective uniform; (3) good cloakroom and toilet accommodation; (4) efficient working conditions; (5) attention to health; here, unfortunately compromise is too often necessary with cases of minor illness. 
In premises, structural faults should be eliminated, and cleaning made easy, i.e. buildings should be vermin-proofed, well lit and ventilated; equipment should be simple, durable, easily manipulated by semi-skilled workers and so installed that cleaning around it is easy. Unsuitable cleaning methods for floors may expose food to dust contamination.

The importance of this background to food hygiene is proved for many housewives who 'couldn't care less' in their old inconvenient kitchens, but, who become veritable paragons in new modern houses with equipment to match. The same is reported of workers in some of the more modern canteens. Unfortunately, the planning in some new types of houses is bad, because the old 'living kitchen' has been replaced by the 'kitchenette', which fills easily with steam and heat from washing and cooking, and has no adequate larder, with the result that it is impossible to keep food cold unless it is banished to the combined bathroom-lavatory.

The actual handling of food must be supervised from time of receipt until time of service. On receipt, the food must be examined; 'off' food must be refused, or kept apart for disposal. The housewife usually selects her own food which will, presumably, be good. If it is not, she will have second thoughts about that particular shop, because, as a result of recent propaganda, she has become more aware of the importance of the handling of food by shop assistants.

Food must be stored in suitable conditions and used in strict rotation. Perishable food should not be stored for longer than necessary and, therefore, ordering and receipt should be timed to coincide with the menu if possible.

Refrigerators are hailed as the answer to most storage problems in homes and canteens; but they frequently give an entirely false feeling of confidence to the workers, who cheerfully misuse them for cooling hot foods and for 'preserving' food already 'off' or grossly contaminated. Food handlers must be taught the correct use of the refrigerator.

The kitchen must be planned to produce a logical sequence of work, with the right equipment for each individual job. This is more difficult in the home than in the canteen; in the former, one sink is so often used for washing crockery, children and vegetables!

Clean methods of handling food are essential, but, in practice, are often sacrificed for the worker's idea of speed and efficiency. Care in the choice of dishes, especially in hot weather, and in the timing of their preparation and cooking should eliminate the need for 'keeping food hot'-usually at incubating temperatures. The continuous cooking and reheating of small quantities is safer, though more difficult to arrange.

Intelligent disposal of scraps is important for both housewife and manageress.

Food to be re-used must be taken at once to the cool larder, and not pushed to the side of the stove 'till later'. All waste should be in covered bins, which, certainly in canteens, should be emptied at the end of the day, and not left overnight in the kitchen. Such bins will be near the washing-up point, and should, therefore be away from both storage and preparation bays.

More stress has been laid on the canteen than on the home, because it is only 
partly possible to legislate about the latter. It would be interesting to know whether more outbreaks of food poisoning begin in homes than in public eating-places. Where home hygiene is poor, the family has often a high resistance, but where homes are clean, immunity is probably acquired late, or not at all. This means, in effect, that a rising standard of hygiene in homes makes the public eating-place proportionately more dangerous.

Other points which have not been mentioned include the whole problem of washing up; those already listed are not new, but they are the kind which still have to be stressed to the majority of food handlers. There are, certainly, food factories, canteens, shops and homes where good food hygiene is practised, but they are in the minority. Unfortunately, clean-food campaigns do not achieve spectacular results, but they may encourage the housewife, who is difficult to reach, to carry over, to her own handling of food in the home, her new awareness of clean food handling.

Canteen manageresses are usually trained people, but a little propaganda now and then, will help them to keep alive their enthusiasm.

And so, the majority of food handlers still require regular, well-directed, educational propaganda to persuade them to handle food with care.

\section{Hygiene in restaurants and public houses}

\section{By T. S. Wilson, Health and Welfare Department, Corporation of Glasgow}

Two investigations were carried out in Glasgow over a period of 2 years, 1954-6. The first was concerned with the standards of hygiene in restaurant kitchens and the second, with similar standards, in licensed establishments.

\section{Restaurant hygiene}

The first survey covered fifty kitchens, arbitrarily divided into ten kitchens of high-class restaurants, thirty of restaurants of good every-day type, and ten belonging to works or office canteens. Visits were made towards the end of the lunch-hour break and without previous warning. Kitchen activity was then at its highest. The methods of investigation adopted were bacteriological examination of swabs of the utensils used, and of wash water and dish-drying cloths. Usually seven items were thus sampled in each kitchen. Cups were swabbed round the rim and over $\frac{1}{2}$ in. in depth on the inner and outer surfaces. Both sides of the prongs of forks were swabbed, both sides of the bowls of spoons and the central area of plates, omitting the rim.

Fourteen of the kitchens were underground, three being in first-class restaurants, ten in the good every-day type of restaurant, and one in the works and offices' canteen group. In several of the underground kitchens the temperature was much too high and the ventilation was proved to be insufficient. In some places the general 